\title{
Short Communication: Species composition and density of mangrove forest in Kedawang Village, Pasuruan, East Java, Indonesia
}

\author{
WAHYU ISRONI ${ }^{1, \bullet}$, R. ADHARYAN ISLAMY ${ }^{2, v »}$, MOHAMAD MUSA ${ }^{2}$, PUTUT WIJANARKO ${ }^{2}$ \\ ${ }^{1}$ Faculty of Fisheries and Marine Science, Universitas Airlangga. Kampus C, Jl. Dharmahusada Permai No.330, Mulyorejo, Surabaya 60115, East Java, \\ Indonesia. "email: isdhary@gmail.com \\ ${ }^{2}$ Faculty of Fisheries and Marine Science, Universitas Brawijaya. Jl. Veteran, Malang 65145, East Java, Indonesia. Tel.: +62-341-553512, \\ vemail: r.adhariyan@gmail.com
}

Manuscript received: 30 March 2019. Revision accepted: 24 May 2019.

\begin{abstract}
Isroni W, Islamy RA, Musa M, Wijanarko P. 2019. Short Communication: Species composition and density of mangrove forest in Kedawang Village, Pasuruan, East Java. Biodiversitas 20: 1688-1692. Mangrove is one of ecosystems located in estuary and shallow coastal waters and its existence has a significant role for life. The aim of this study was to identify species composition and density of mangrove forest in Kedawang village, Nguling Sub-district, Pasuruan District, East Java, Indonesia. Survey method using belt transects was carried at three sampling points. Results of this study showed that mangrove vegetation in Kedawang includes five species from three families, namely Avicenniaceae (Avicennia alba and Avicennia marina), Rhizophoraceae (Rhizophora apiculata and Rhizophora mucronata), and Sonneratiace (Sonneratia alba). At sampling point 1, A. alba dominated with a density of 37 individuals/ha at tree level, 380 individuals/ha at pole level and 3100 individuals/ha at stake level. At sampling point 2, the tree level was dominated by $A$. alba with 142 individuals/ha, while $R$. mucronata dominated the pole and stake level with 1300 and 1467 individuals/ha, respectively. At sampling point 3, the pole and stake level was dominated by A. alba with 167 and 933 individuals/ha respectively, while A. marina dominated the sapling level with 800 individuals/ha. At all stations, the density at stake level is greater than that tree level. Therefore, it is necessary to carry out conservation efforts in the form of protection combined with restoration by enrichment planting at all study locations to increase the diversity and density of mangrove vegetation.
\end{abstract}

Keywords: Avicennia marina, forest, mangrove, Rhizopora apiculata, Sonneratia alba

\section{INTRODUCTION}

Mangrove is one of ecosystems located in estuary and shallow coastal waters. In the tropics, mangrove forest is the dominant ecosystem type in estuarine area. The existence of mangroves has a significant role for life since in mangrove ecosystem there are various types of biological resources that can be utilized for human welfare (Tuwo 2011). Ecosystem of mangrove is ecologically and economically importance (Shing et al. 2014). Mangrove forest, which is in between land and sea interface, provides food, breeding grounds and nursery sites for a variety of terrestrial and marine organisms (Igulu et al. 2014). Mangrove forest is highly productive ecosystem with rates of primary production are equal to those of tropical humid evergreen forests, accumulating carbon in tree biomass and most of this carbon is lost by decomposition and exported to adjacent ecosystems (Alongi 2002). Mangroves also play a key role in human livelihoods, being heavily used for food, timber, fuel and medicinal purposes (Saenger et al. 2002). They serve as protection from catastrophic events, such as tsunami, tropical cyclones, and tidal bores and can dampen shoreline erosion (Alongi 2008). While the socioeconomic functions of mangrove ecosystem include as a source of building materials, wood, medicines, food, and beverage ingredients as well as areas for agriculture, fisheries and tourism (Anwar and Gunawan 2006).

Nowadays, in addition to intense local and regional impacts on mangroves, global climate change is putting pressure on the dynamics of mangrove ecosystems and their communities with scale and intensity are still uncertain (FAO 2007). Changes in temperature, rainfall, and elevations of sea level have the potential to change existing hydrological and biogeochemical characteristics, threatening the biodiversity and ecological balance of mangroves (Gilman et al. 2008; Soares 2009). These dynamics also occur in coastal mangrove forest in Pasuruan District, East Java Province which has been degraded in both the extent of area and biological diversity. The main causes of the disturbances in the area are economic factors and the lack of understanding of the people in Pasuruan, especially in Kedawang village, about the ecological functions of mangrove forests, leading to increased illegal logging and the conversion of mangrove forests into ponds (Chatarina et al. 2011).

The structure and composition of mangrove species directly influence the conditions and functioning of mangrove forests, and its alteration may affect the distribution and abundance of fauna (Soares 1999; Cavalcanti et al. 2009). Therefore, characterization of mangrove forest constitutes an important tool in understanding how this ecosystem responds to existing 
environmental conditions, aiding in studies to preserve its existence. As an example, extracting or cutting mangrove trees for land conversion will reduce the energy available within the ecosystem, decreasing productivity and leading to smaller structural vigor of forest, especially in term of average height, diameter, basal area and density of mangrove trees (Peria et al. 1990; Souza and Sampaio 2001; Atheull et al. 2009). The aim of this study was to identify species composition and density of mangrove forest in Kedawang village, Pasuruan District, East Java Province, Indonesia.

\section{MATERIALS AND METHODS}

\section{Study location}

This research was conducted at mangrove forest in Kedawang village, Nguling Sub-district, Pasuruan District, East Java Province, Indonesia from January to February 2018 (Figure 1). Point and sampling locations were determined based on differences in land use. Determination of stations was done by purposive sampling, which is a method of determining the location of data collection carried out based on the consideration of individuals or researchers at the location of the study (Fachrul 2006). The research station was determined subjectively based on the representativeness of the location according to topographical condition as well as the characteristics of the region (Juwita et al. 2015). Sampling locations were divided into three locations: (i) Sampling point 1: near the boat port and close to the residential area; (ii) Sampling point 2: within the mangrove forest area and located 200 meters to the east from sampling point 1 . This location is an area near the coast and there is a river flow; (iii) Sampling point 3: within the mangrove forest area and located 500 meters to the east from sampling point 2. This location is near the beach in which there is an area of aquaculture.

\section{Sampling procedures}

The method used for mangroves sampling was belt transect with three replications for each station. The choice of belt transect was based on the richness and diversity of mangrove species in the study location with consideration to the general appearance of the stand, so that the profile diagram created can represent the mangrove vegetation in that location. The belt size of the transect was $60 \times 10 \mathrm{~m}^{2}$. Six squared plots with size of $10 \times 10 \mathrm{~m}^{2}$ were created for data collection. The direction of transects from sea/estuary to land was expressed as the $x$ axis, while the width of the transect as the $y$ axis and the vertical direction as the $z$ axis. There was obtained $x$ axis with $60 \mathrm{~m}$ length, $y$ axis with 10 $\mathrm{m}$ width, and $z$ axis with $20 \mathrm{~m}$ height. The $z$ axis determination of only $20 \mathrm{~m}$ was based on the fact that mangrove trees in the research location were $<20 \mathrm{~m}$ high. Similar method of belt transect also was used in the analysis of vegetation composition and structure by Setyawan et al. (2005). All tree, sapling and shrub species within the plots were sampled and identified.

Species identification referred to published method (Backer and Bakhuizen van den Brink 1963; Tomlison 1986; Kitamura et al. 1997; Ng and Sivasothi 2001a,b). Furthermore, all trees, saplings and shrubs were numbered and their positions were determined against the $x$ and $y$ axis, then were measured of the total height, height of the first branch, width and length of the canopy, and diameter at breast height (diameter at breast high/DBH: $130 \mathrm{~cm}$ ), and were drawn vertically on graph paper. Fallen trees were recorded of their length, diameter, and position on the $x$ and $y$ axes, and drawn on graph paper. The data was then tabulated followed by projecting the canopy onto the surface of forest floor to create vertical profile diagram of the vegetation. Based on this forest profile, several tree strata were determined (Aumeeruddy 1994; Baker and Wilson 2000). The determination of tree strata depended on personal decision of the researcher (Grubb et al. 1963).

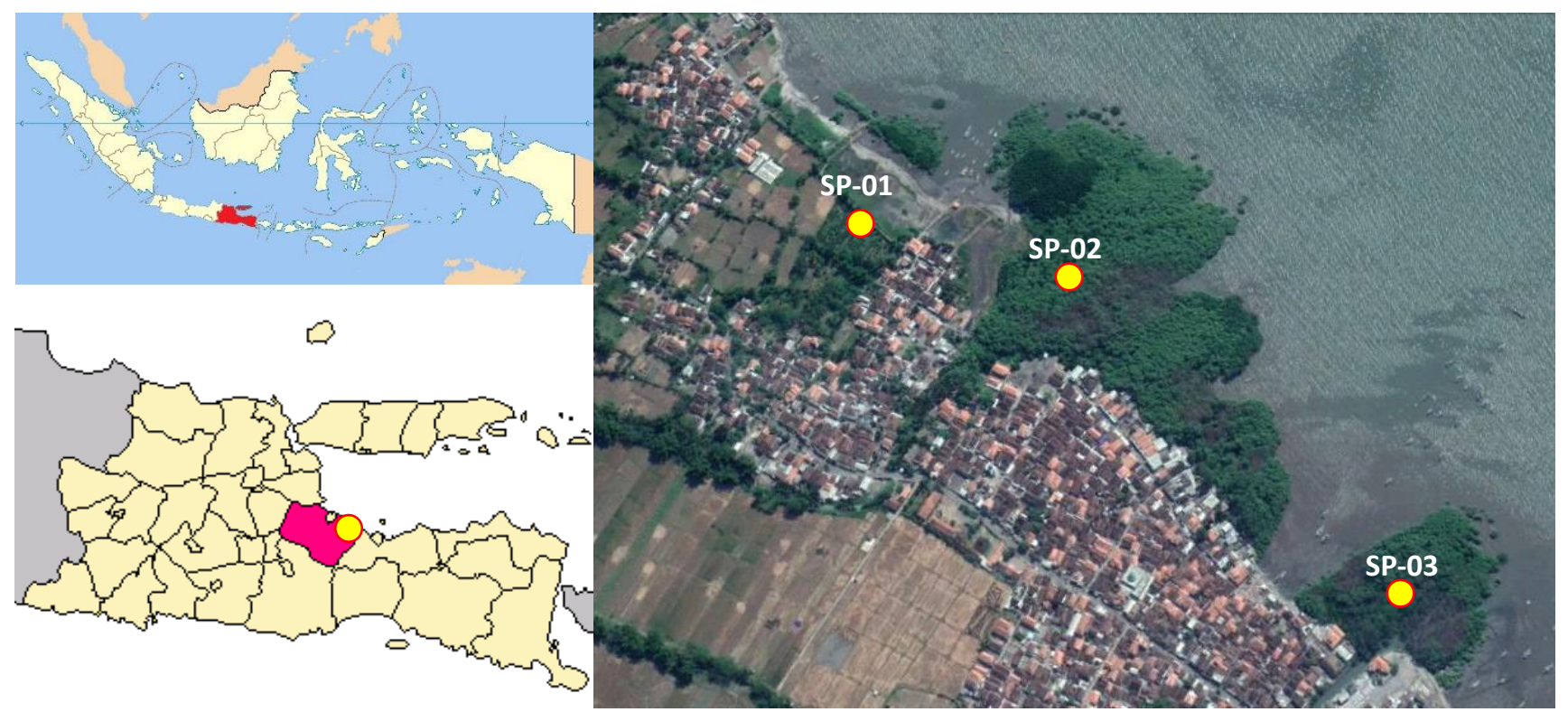

Figure 1. Sampling point location at mangrove forest in Kedawang village, Nguling Sub-district, Pasuruan District, East Java Province, Indonesia. SP-01: Sampling Point 1, SP-02: Sampling Point 2, SP-03: Sampling Point 3 


\section{RESULTS AND DISCUSSION}

\section{Mangrove vegetation}

There were five species from three families found at the studied area of mangrove forest in Kedawang village, Nguling Sub-district, Pasuruan District, namely Avicennia alba and Avicennia marina (Avicenniaceae), Rhizophora apiculata and Rhizophora mucronata (Rhizophoraceae), and Sonneratia alba (Sonneratiaceae). The distribution of mangrove species in each sampling point is shown in Table 1. Based on Table 1, A. alba was found at each plot of all sampling points, describing the condition of mangrove vegetation in Kedawang village. While $S$. alba, $R$. apiculata, and A. marina were rarely found.

\section{Sampling point 1}

There were only one species of mangrove found at sampling point 1, i.e., A. alba from Avicenniaceae family with density of 37 trees/ha, 380 poles/ha and 3100 stakes/ha (Figure 5). Sampling point 1 only had A. alba which is presumably because the state of the mangrove vegetation in this area is still natural and is located directly opposite to the sea with soil composed by sandy substrate. Avicenniaceae zone is located at the farthest or closest to sea where the condition of the soil is rather soft (shallow) muddy (Pramudji 2001). Avicennia spp. is a genus that has the ability to tolerate a wide range of salinity, even this species grow in coastline areas that have high salinity (Pramudji 2000). Based on Figure 5, the density of A. alba at stake level is greater than of trees and saplings.

\section{Sampling point 2}

At sampling point 2, there were three species of mangrove, i.e. A. alba (Avicenniaceae), R. mucronata (Rizhophoraceae) and $S$. alba (Sonneratiaceae) (Figure 6). At tree level, A. alba had the highest density with 142 individuals/ha while $R$. mucronata and $S$. alba consist of 17 individuals/ha for each species. The high density of A. alba species at sampling point 2 is likely because this station is natural mangrove vegetation where the dominance of $A$. alba is common.

At pole level, mangrove species with the highest density was $R$. mucronata with 1300 individuals/ha while A. alba had density of 833 individuals/ha. The high density of $R$. mucronata is understandable as this area had been the location of planting of $R$. mucronata.

At stake level, $R$. mucronata was also the species with the highest density with 1467 individuals/ha, while $S$. alba was the lowest with 13 individuals/ha. This is likely because the sandy clay substrate at this station which is not suitable for the life of $S$. alba as according to Noor et al. (1999) $S$. alba commonly grows on sandy beaches or even rocky beaches.

Based on density, species that dominates sampling point 2 at tree level was $A$. alba while at the levels of pole and stake was $R$. mucronata. The density of $R$. mucronata at stake level is greater than its density at tree level because $R$. mucronata have been planted at this location. Therefore, conservation effort in the form of protection is necessary to maintain the planted species grow well until they reach maturity.

\section{Sampling point 3}

There were three species of mangrove at sampling point 3, including A. alba and A. marina (Avicenniaceae) and $R$. mucronata (Rizhophoraceae). The mangrove vegetation at tree level in sampling point 3 was dominated by A. alba with density of 167 individuals/ha. Similarly, at pole level, mangrove species with the highest density was A. alba (933 individuals/ha). In agreement with other sampling units, the high density of $A$. alba at tree and pole level is because these species have been naturally grown in mangrove forest in Kedawang village. Different composition is shown at stake level in which A. marina dominated the area with 800 individuals/ha followed by A. alba and R. apiculata with density of 666 and 133 individuals/ha, respectively.

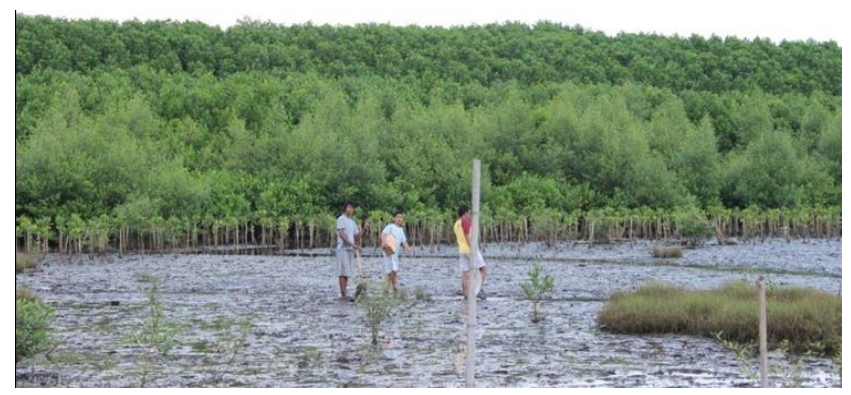

Figure 2. Sampling point 1

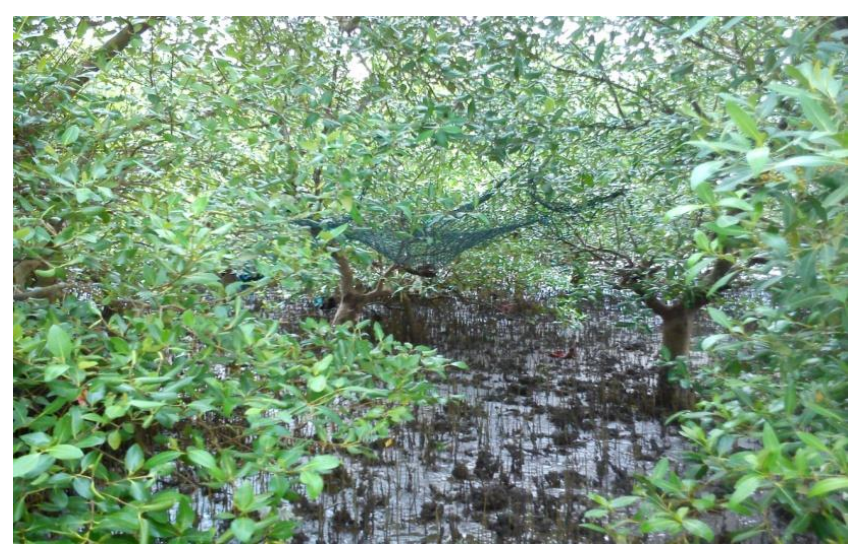

Figure 3. Sampling point 2

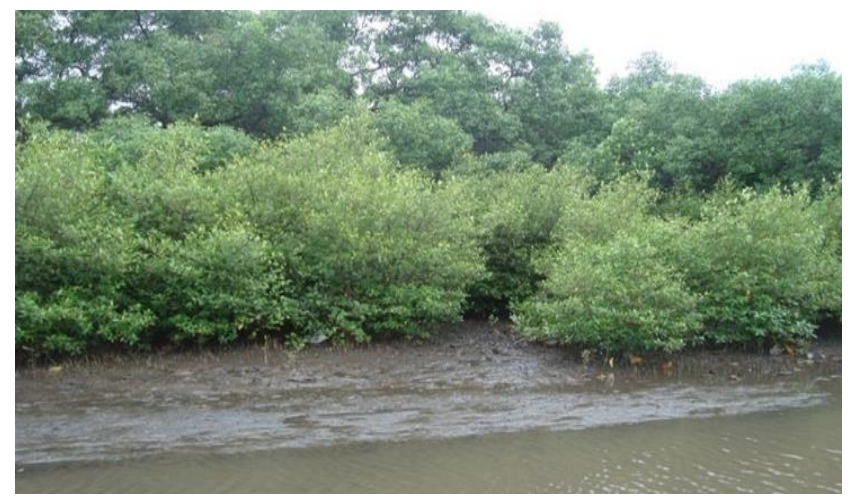

Figure 4. Sampling point 3 
Table 1. Vegetation and distribution of mangrove at the studied areas in mangrove forest of Kedawang village, Nguling Sub-district, Pasuruan District, East Java Province, Indonesia

\begin{tabular}{|c|c|c|c|c|c|c|c|c|c|c|}
\hline \multirow{2}{*}{ Family } & \multirow{2}{*}{ Species } & \multicolumn{3}{|c|}{ Sampling point 1} & \multicolumn{3}{|c|}{ Sampling point 2} & \multicolumn{3}{|c|}{ Sampling point 3} \\
\hline & & 1 & 2 & 3 & $\mathbf{1}$ & 2 & 3 & $\mathbf{1}$ & 2 & 3 \\
\hline \multirow[t]{2}{*}{ Avicenniaceae } & Avicennia alba & + & + & + & + & + & + & + & + & + \\
\hline & Avicennia marina & - & - & - & - & - & - & + & - & - \\
\hline Sonneratiaceae & Sonneratia alba & - & - & - & + & + & - & - & - & - \\
\hline \multirow[t]{2}{*}{ Rhizophoraceae } & Rhizopora mucronata & - & - & - & + & + & + & - & - & - \\
\hline & Rhizophora apiculata & - & - & - & - & - & - & + & - & - \\
\hline
\end{tabular}

Note: 1, 2 and 3 refers to replication of sampling. (+): found; (-): not found

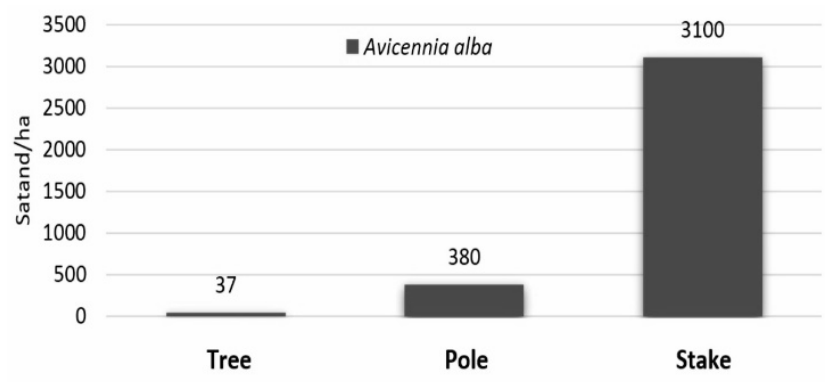

Figure 5. The density of mangrove species at sampling point 1

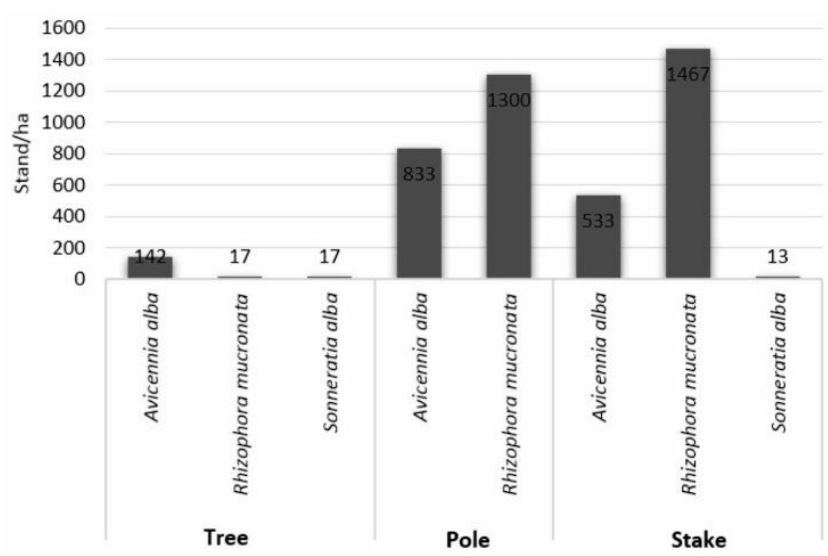

Figure 6. The density of mangrove species at sampling point 2

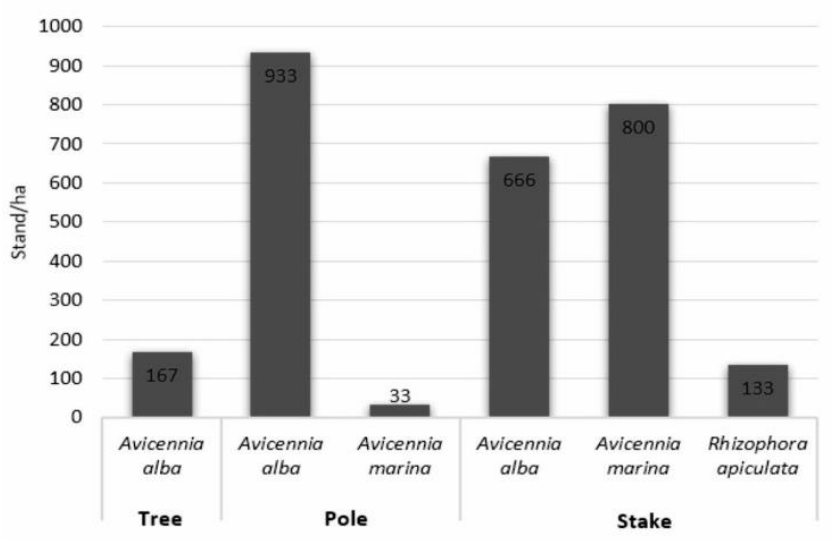

Figure 7. The density of mangrove species at sampling point 3
The value of biological diversity of a community depends on the number of species and the number of individuals contained in the community. The diversity of a community will be high if it is composed by many species with no species dominates. Conversely, a community has a low value of biodiversity if the community is composed by few species with dominance of particular species (Indriyanto 2006)

In sampling points 1, 2 and 3, species which most commonly found was Avicennia. This is because Avicennia mangroves have generally large stem and broad canopy so that it tends to dominate other species. The dominance of Avicennia also reflects the ability to tolerate environmental conditions (Nasution 2005). In addition, this species can adapt to extreme conditions so that they can compete to obtain more nutrients than other species (Fadli et al. 2015). The high density of mangrove vegetation indicates that the vegetation community is in a condition that has no disturbance (Erwin 2005).

In conclusion, the mangrove vegetation in Kedawang village includes five species from three families, namely Avicenniaceae (A. alba and A. marina), Rhizophoraceae (R. apiculata and $R$. mucronata), and Sonneratiaceae $(S$. alba). At sampling point $1, A$. alba was found with density of 37 individuals/ha at tree level, 380 individuals/ha at pole level and 3100 individuals/ha at stake level. At sampling point 2, the highest density was A. alba with 142 individuals/ha at tree level, $R$. mucronata with 1300 individuals/ha at pole level and 1467 individuals/ha at stake level. At sampling point 3, the pole and stake level were dominated by $A$. alba with 167 individuals/ha and 933 individuals/ha, respectively, while at sapling level the highest density was A. marina with 800 individuals/ha. At all sampling points, the density at stake level is greater than that at tree level. For this reason, it is necessary to carry out conservation efforts in the form of protection combined with restoration by enrichment planting at all study locations because the occurrence of some species is not evenly distributed.

\section{REFERENCES}

Alongi DM. 2002. Present state and future of the world's mangrove forests. Environ Conserv 29: 331-349.

Alongi, DM. 2008. Mangrove forests: Resilience, protection from tsunamis, and responses to global climate change: Estuarine, coastal and shelf science. Estuar Coast Shelf Sci 1: 1-13. 
Anwar C, H Gunawan. 2006. Peranan ekologis dan sosial ekonomis hutan mangrove dalam mendukung pembangunan wilayah pesisir. Prosiding Ekspose Hasil-Hasil Penelitian. Konservasi dan Rehabilitasi Sumberdaya Hutan. Padang, 20 September 2006. [Indonesian]

Atheull AN, Din N, Longonje SN, Koedam N, Dahdouh-Guebas F. 2009. Commercial activities and subsistence utilization of mangrove forests around the Wouri estuary and the Douala-Edea reserve (Cameroon). J Ethnobiol Ethnomed 5: 1-14.

Aumeeruddy Y. 1994. Local representations and management of agroforests on the periphery of Kerinci Seblat National Park. Sumatra. Indonesia. People and Plants Working Paper 3. UNESCO, Paris.

Backer CA, Bakhuizen van den Brink RC Jr. 1963. Flora of Java. P. Noordhoff, Groningen.

Baker PJ, Wilson JS. 2000. A quantitative technique for the identification of canopy stratifies in tropical and temperate forests. For Ecol Manag 127: 77-86.

Cavalcanti VE, Soares MLG, Estradat GCD, Chavest FO. 2009 Evaluating mangrove conservation through the analysis of forest. J Coast Res 56: 390-394.

Chatarina M, Ahmad SN, Trisni U. 2011. Model pemberdayaan masyarakat dalam pengelolaan dan pelestarian hutan mangrove di pantai Pasuruan Jawa Timur. Jurnal Manusia dan Lingkungan 2: 75 84. [Indonesian]

Erwin. 2005. Studi kesesuaian lahan untuk penanaman mangrove ditinjau dari kondisi fisika oseanografi dan morfologi pantai pada Desa Sanjai-Pasi Marannu, Kab. Sinjai. [Thesis]. Hasanuddin University, Makassar. [Indonesian]

Fachrul MF. 2006. Metode Sampling Bioekologi. Bumi Aksara, Jakarta.

Fadli, Khairijon, Nery S. 2015. Analisis vegetasi Avicennia sp. dan karakteristik sedimen di kawasan mangrove Desa Sungai Rawa Kecamatan Sungai Apit, Kabupaten Siak, Riau. Jurnal Online Mahasiswa Fakultas Matematika dan Ilmu Pengetahuan 1: 23-34. [Indonesian]

FAO. 2007. The world's mangrove: 1980-2005-A thematic study prepared in the framework of the Global Forest Resources Assessment. Food and Agriculture Organization of the United Nations, Rome.

Gilman EL, Ellison J, Duke NC, Field C. 2008. Threats to mangroves from climate change and adaptation options: A review. Aquat Bot 89: 237-250.

Grubb PJ, Lloyd JR, Pennington TD, Whitmore TC. 1963. A comparison of montane and lower rain forest in Ecuador. I. The forest structure. physiognomy and floristics. J Ecol 51: 567-601.

Igulu MM, Nagelkerken I, Dorenbosch M, Grol MGG, Harborne AR, Kimirei IA, et al. 2014. Mangrove habitat use by juvenile reef fish: Meta-analysis reveals that tidal regime matters more than biogeographic region. PLoS ONE 9 (12): e114715. DOI: 10.1371/journal.pone.0114715.

Indriyanto. 2006. Ekologi Hutan. Bumi Aksara, Jakarta. [Indonesian]

Juwita E, Soewardi K, Yonvitner. 2015. Kondisi habitat dan ekosistem mangrove Kecamatan Simpang Pesak, Belitung Timur untuk pengembangan tambak udang. Jurnal Manusia dan Lingkungan 22 (1): 59-65. [Indonesian]

Kitamura S, Anwar C, Chaniago A, Baba S. 1997. Handbook of Mangroves in Indonesia; Bali \& Lombok. The Development of Sustainable Mangrove Management Project. Ministry of Forest Indonesia, Denpasar and Japan International Cooperation Agency, Kyoto.

Nasution SR. 2005. Perbedaan struktur dan komposisi hutan mangrove di Kawasan Muara Sungai Mesjid Kota Administratif Dumai [Thesis]. Faculty of Fisheries and Marine Science. Riau University, Pekanbaru. [Indonesian]

Ng PKL, Sivasothi N. 2001a. A Guide to Mangroves of Singapore. Volume 1: The Ecosystem and Plant Diversity The Singapore Science Centre. Singapore.

Ng PKL, Sivasothi N. 2001b. A Guide to Mangroves of Singapore. Volume 2: Animal Diversity. The Singapore Science Centre. Singapore.

Noor RY, Khazali M, Suryadiputra INN. 1999. Panduan Pengenalan Mangrove di Indonesia. PKA/WI-IP, Bogor. [Indonesian]

Peria LCS, Fernandes PPCP, Menezes GV, Grasso M, Tognella MMP. 1990. Estudos estruturais comparativos entre bosques de manguezais impactados (Canal da Bertioga) e não impactados (Ilha do Cardoso), estado de São Paulo. Segundo Simpósio de Ecossistemas da Costa Brasileira. Estrutura. Função e Manejo. ACIESP 2: 183-193.

Pramudji 2001. The dinamic of mangrove forest area in the coastal zone of Kotania Bay, West Ceram. Oseana 26 (3): 9-16.

Pramudji. 2000. Hutan mangrove di Indonesia: Peranan permasalahan dan pengelolaannya. Oseana 25 (1): 13-20. [Indonesian]

Saenger P. 2002. Mangrove Ecology, Silviculture and Conservation. Kluwer Academic Press, Dordrecht, Boston, London.

Setyawan AD, Indrowuryatno, Wiryanto K, Winarno, Susilowati A. 2005. Mangrove plants in coastal area of Central Java: 2. Floristic composition and vegetation structure. Biodiversitas 6 (3): 194-198. [Indonesian]

Shing YL, Jurgene HP, Dahdouh-Guebas F, McKee K, Jared OB, Stefano C, Karen D, Francois F, Nico K, Cyril M, Irving M, Nibedita M, Sydne R. 2014. Ecological role and services of tropical mangrove ecosystems: A reassessment. Global Ecol Biogeogr 23: 726-743.

Soares MLG. 1999. Estrutura vegetal e grau de perturbação dos manguezais da lagoa da Tijuca, Rio de Janeiro, RJ, Brasil. Revista Brasileira de Biologia 59: 5003-5015.

Soares MLG. 2009 A conceptual model for the responses of mangrove forests to sea level rise. J Coast Res 56: 267-271.

Souza MMA, Sampaio EVSB. 2001. Variação temporal da estrutura de bosques de mangue de Suape-PE após a construção do Porto. Acta Bot Brasilica 15: 1-12.

Tomlison PB. 1986. The Botany of Mangrove. Cambridge Univ., Cambridge.

Tuwo A. 2011. Pengelolaan ekowisata pesisir dan laut-suatu pendekatan ekologi, sosial-ekonomi, kelembangaan, dan sarana wilayah. Brilian Internasional Surabaya 1: 11-26. [Indonesian] 